first Italian woman to obtain the degree of M.D. Her first notable work was with mental defectives, with whom she used methods based on those of Séguin. With some of the children classified as mental defectives she obtained results which were acclaimed as remarkable, some of her children doing better than the (supposed) normal children in the State examination.

We know now, however, how unreliable the detection of mental deficiency was in those daysand even to-day by inadequately trained psychologists or medical men. Probably some of Dr. Montessori's mental defectives were appreciably above the borderline in intelligence, and some of the supposed 'normal' below.

Shortly afterwards, Dr. Montessori began to apply her ideas to normal children, maintaining that methods good for mentally deficient children were appropriate for very young children. Her originality consisted chiefly in two things : first, her elaborate apparatus for 'sense-training', which was selfchecking so that the child found out his errors without correction; and second, in her doctrine that the child should be free to choose his activities. Her main influence, however, was through her charm of personality, her intense love of little children, and her unbounding enthusiasm for reform - social or educational - which would benefit them.

Her first and best book, "The Montessori Method", attempts a justification of her views about sensetraining, but with serious psychological fallacies. No doubt substantial gains in knowledge of shapes and colours and in hand control came as a result of play with the apparatus; but the main truth behind Dr. Montessori's practice was that it is better for dull and very young children to play about for a time with things of slight or even of no educational value, rather than to be prematurely forced, as they usually were in those days, to begin reading and arithmetic when quite unable to make any progress, and so develop an antagonism to such work and become hopeless about their own abilities.

The common idea that Montessori advocated complete freedom for the children is quite wrong. She states that "it is necessary to hinder... with absolute rigour . . . and little by little suppress, all those things which we must not do". She was also right, however, in maintaining that to provide the child with work precisely adapted to his stage of development, is to make much repressive discipline in the school unnecessary. C. W. VALENTINE

\section{Dr. W. R. Ivimey Cook}

Dr. Ivimey Cook, whose recent death at the age of fifty, after a short illness, will be deeply regretted by his wide circle of friends, was senior lecturer in botany at University College, Cardiff. $\mathrm{He}$ was educated at Dulwich College and later at King's College, University of London, where he took his Ph.D. degree, and for some time acted as demonstrator. Afterwards he was appointed assistant lecturer at the University of Bristol, where he remained for four and a half years; eventually transferring to University College, Cardiff.

Dr. Cook was, of course, primarily a mycologist, and his work on Archimycetes and especially on the Plasmodiophorales was widely known and appreciated. While at Cardiff he organized a considerable series of researches, in collaboration with pupils, on the Phycomycetes, which added greatly to our knowledge of the group in Britain. These he intended to publish as a collected work; but post-war costs forced postponement of the plan.

His name was familiar to several generations of medical students as co-author, with Dr. Hentschel, of "Biology for Medical Students", a very successful text-book, now in its fourth edition. He was also co-author of "Plant Science Formulæ" and "Practical Field Ecology", and was collaborating in the production of two large general text-books, on theoretical and practical botany respectively; but at the time of his death only one of these volumes had appeared. He was also planning and had almost finished a book on economic botany in which he was deeply interested.

Dr. Cook was a man of indefatigable energy and wide interests, and he was one of the hardest workers I have ever known. No man ever threw himself more unselfishly into his work, and the Department of Botany at Cardiff owes him a great debt for the many developments he carried through. A fact not generally known is that he was one of the first to give the impetus to the scheme for the national training of laboratory technicians, which has recently come to fruition. During the War he served as a special constable and also found time to run a smallholding, on which he raised almost every kind of livestock, all without any relaxation of his professional duties. Home and garden, camping and canoeing were his pleasures and contributed much to a life lived to the full.

His cheerful, friendly presence, his very human love of discussion and his remarkable flair for organization will long be missed in his College and wherever botanists are forgathered.

$$
\text { R. C. McLean }
$$

\section{Dr. F. Earnshaw}

Dr. Frederick Earnshaw, who died in Edinburgh on April 27, was borm in 1914. He was a student at the University of Cambridge during 1933-37. In 1937 he was appointed assistant lecturer in botany at the Edinburgh and East of Scotland College of Agriculture, relinquishing the post on joining the Army in 1940. During the period 1937-40 he also worked as a research student at the Scottish Plant Breeding Station and prepared a thesis entitled "Genetical and Cytological Studies in the Genus Plantago" which gained him the degree of Ph.D. at the University of Edinburgh.

After returning from the Army in 1946, Earnshaw joined the staff of the National Institute of Agricultural Botany, Cambridge, as an economic botanist, and while there conducted work on varietal differences in cereals.

In 1949 a new post of genecologist having been established at the Scottish Plant Breeding Station, Earnshaw left Cambridge and returned to Edinburgh to revive a programme of genetical ecological investigations which had been intermupted during the War. He is survived by his wife, two sons and a daughter.

WE regret to announce the following deaths :

Dr. F. W. Carter, F.R.S., lately consulting engineer to the British Thomson-Houston Co., Ltd., on May 29, aged eighty-one.

Colonel L. Newcombe, C.B.E., librarian and secretary to the Trustees, National Central Library, during 1926-44, on May 25, aged seventy-two. 